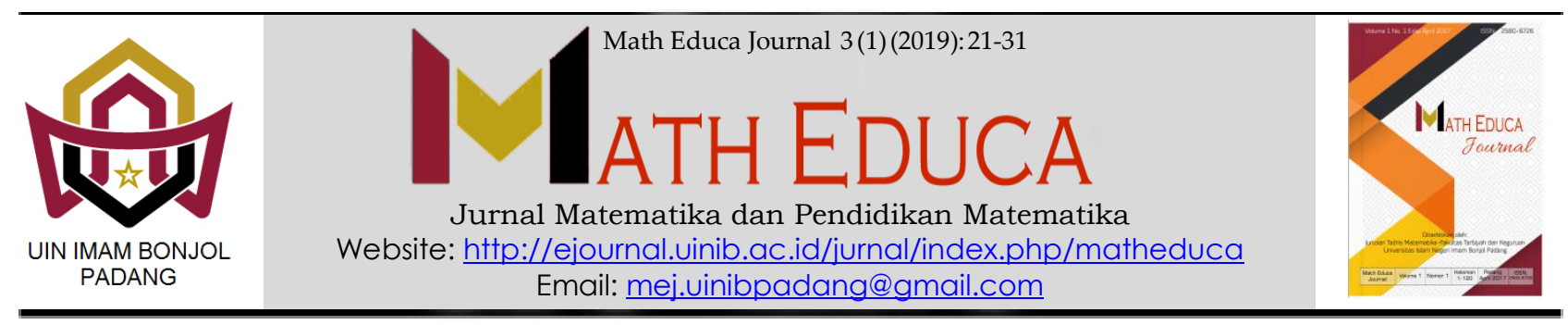

\title{
STRATEGI BELAJAR THINK TALK WRITE DAN KEMAMPUAN BERPIKIR LOGIS MATEMATIS
}

\author{
'Reni Septia Pratiwi, ${ }^{2}$ Martin Kustati, ${ }^{3}$ Andi Susanto \\ Tadris Matematika, Tarbiyah dan Keguruan, UIN Imam Bonjol Padang, Indonesia \\ Email: 1renipratiwi363@gmail.com, ${ }^{2}$ martinkustati@yahoo.com, ${ }^{3}$ soulmath_andi@yahoo.co.id
}

Received: January 2019; Accepted: March 2019; Published: April 2019

\begin{abstract}
Abstrak
Tujuan penelitian ini mengetahui kemampuan berpikir logis peserta didik yang belajar dengan strategi Think Talk Write kelas VIII MTsN Kota Solok. Penelitian ini adalah eksperimen semu dengan rancangan Randomized Control Group Only Design. Teknik pengambilan sampel random sampling. Terpilih kelas eksperimen $\mathrm{VIII}_{\mathrm{G}}$ dan kelas kontrol $\mathrm{VIII}_{\mathrm{E}}$. Instrumen penelitian ini tes kemampuan berpikir logis matematis. Berdasarkan hasil tes, diperoleh rata- rata kelas eksperimen 80,81 lebih tinggi dari kelas kontrol yaitu 75,03. Uji hipotesis dengan uji-t menunjukkan bahwa kemampuan berpikir logis matematis peserta didik kelas eksperimen lebih tinggi dari siswa kelas kontrol.

Kata kunci: Kemampuan berpikir logis matematis, Strategi Think Talk Write

Abstract

The purpose of this study was to find out the logical thinking skills of students who learn with Solok City's Solok Think Talk Write class VIII strategy. This research is a quasi-experimental design with Randomized Control Group Only Design. Random sampling technique. The experimental class VIIIG and the VIIIE control class were selected. The instrument of this study tests mathematical logical thinking skills. Based on the results of the test, the average experimental class was 80.81 higher than the control class of 75.03. Hypothesis testing with t-test shows that mathematical logical thinking ability of experimental class students is higher than control class students.
\end{abstract}

Keywords: Ability of mathematical logical thinking, Think Talk Write strategies

\section{PENDAHULUAN}

Salah satu kemampuan yang dituntut dalam belajar matematika adalah kemampuan

${ }^{*}$ Corresponding author.

Peer review under responsibility UIN Imam Bonjol Padang.

(C) 2019 UIN Imam Bonjol Padang. All rights reserved.

p-ISSN: 2580-6726

e-ISSN: 2598-2133 berpikir logis matematis. Berpikir merupakan aktivitas seseorang untuk mengumpulkan ideide atau informasi- informasi yang ada dengan cara menghubungkan antara bagian- bagian 
informasi yang ada tersebut dengan masalah yang sedang dihadapi pada diri seseorang. Kemudian Ibrahim dan Nur (2000) Pengertian berpikir adalah kemampuan untuk menganalisis, mengkritik, dan mencapai kesimpulan berdasarkan pada inferensi, atau pertimbangan yang seksama. Berarti kemampuan menganalisis, mengkritik dan mencapai suatu kesimpulan selalu berdasarkan inferensi atau judgement, dengan demikian berpikir merupakan proses yang kompleks dan non-algoritmik. Glatthorn \& Baron ( dalam Tantan 2015: 5) menyatakan bahwa berpikir dimulai dengan meragukan sesuatu yang harus dilakukan atau dipercaya. Lebih jauh disebutkan bahwa sebagaimana dicatat oleh Dewey, bahwa semua pikiran sadar berasal dari ketidakpastian.

Dalam hal ini, berpikir berarti suatu proses atau kegiatan untuk menemukan suatu kebenaran atau pengetahuan yang benar. Kata benar dimungkinkan berbeda bagi setiap orang, sehingga kegiatan proses berpikir juga menghasilkan kebenaran pengetahuan yang berbeda pula. Oleh sebab itu, kriteria kebenaran yang merupakan landasan suatu proses penemuan kebenaran tersebut menjadi sangat penting. Menurut Asril (2017), kemampuan berpikir logis dalam pembelajaran matematika perlu ditingkatkan karena dapat membantu peserta didik meningkatkan kemampuan dalam matematika yaitu dari yang hanya sekedar mengingat kepada kemampuan pemahaman. Pentingnya kemampuan berpikir logis atau penalaran dalam pembelajaran matematika juga dikemukakan oleh Mullis dan Suryadi (dalam Asril, 2017:3) yang menyatakan bahwa pembelajaran lebih menekankan pada aktifitas penalaran dan pemecahan masalah sangat erat kaitannya dengan pencapaian prestasi peserta didik yang tinggi. Uraian di atas menunjukkan bahwa kemampuan berpikir logis dalam matematika merupakan faktor yang sangat penting bagi perkembangan kognitif peserta didik dan dapat mempengaruhi hasil belajar peserta didik.

Albrecht (dalam Tantan, Ali 2015; 4) menyatakan bahwa berpikir logis atau berpikir runtun didefinisikan sebagai proses mencapai kesimpulan menggunakan penalaran secara konsisten. Seseorang yang memiliki kemampuan berpikir logis matematis memiliki ciri diantaranya mampu berpikir menurut aturan logika, berdasarkan struktur, menurut urutan yang sesuai, mengklasifikasi, mengkategorisasi dan mampu menganalisis angka-angka serta memiliki ketajaman dalam berspekulasi dengan menggunakan kemampuan logikanya. Menurut Sumarmo (2012: 7) manyatakan bahwa indikator berpikir logis yang pertama yaitu mengidentifikasi hubungan antar fakta dalam menyelesaikan masalah, kedua yaitu menyelesaikan permasalahan dengan memberikan alasan, indikator ketiga yaitu membuat kesimpulan berdasarkan keserupaan dua proses. 
Ketidaktepatan pendidik dalam merancang dan melaksanakan pembelajaran menjadi salah satu faktor penyebab prestasi belajar matematika peserta didik rendah. Kemampuan berpikir logis matematis penting diterapkan dalam proses pembelajaran, tetapi kemampuan berpikir logis belum menjadi perhatian pendidik, dikarenakan dalam proses pembelajaran masih berpusat pada pendidik. Untuk mengatasi hal tersebut, cara yang dilakukan adalah dengan menerapkan strategi pembelajaran yang relevan oleh pendidik. Menurut Suherman (2003: 4) Strategi adalah siasat yang sengaja direncanakan oleh pendidik, berkenaan dengan segala pembelajaran agar pelaksanaan pembelajaran berjalan lancar.

Observasi menunjukkan bahwa kemampuan berpikir logis rendah, salah satu strategi yang digunakan yaitu Think Talk Write. Berdasarkan penelitian sebelumnya menunjukkan bahwa strategi ini dapat mengembangkan kemampuan berrpikir logis matematis. Strategi ini dapat digunakan untuk membantu peserta didik mengkonstruksi pengetahuannya sendiri sehingga kemampuan berpikir logisnya lebih tinggi. Strategi ini diperkenalkan oleh Huinker \& Laughlin. Ada beberapa tahapan dalam strategi Think Talk Write yaitu berpikir (think), berbicara (talk) dan menulis (write).

Dalam kegiatan pembelajaran matematika sering ditemui bahwa ketika peserta didik diberikan tugas tertulis, peserta didik selalu mencoba untuk langsung memulai menulis jawaban. Walaupun hal itu bukan sesuatu yang salah, namun akan lebih bermakna jika terlebih dahulu melakukan kegiatan berpikir, merefleksikan dan menyusun ide-ide, serta menguji ide-ide itu sebelum memulai menulisnya.

Strategi Think Talk Write dikembangkan melalui proses berpikir (think), berbicara (talk) dan menulis (write). Dimulai dari keterlibatan peserta didik dalam berpikir sendiri setelah membaca materi selanjutnya berbicara atau membagikan ide dengan teman dan dilanjutkan dengan menuliskan laporan atau kesimpulan.

Menurut Huda (2013: 218) Tahapan think dimulai dengan keterlibatan peserta didik dalam berpikir atau berdialog dengan dirinya sendiri setelah membaca LKPD yang diberikan. Kegitan berpikir dapat dilihat dari proses peserta didik membaca dan membuat catatan dari apa yang telah dibacanya. Kegiatan ini dapat meningkatkan keterampilan berpikir peserta didik.

Tahapan selanjutnya talk, peserta didik berbicara atau mengkomunikasikan hasil pemikirannya dalam diskusi dan berbagi (sharing) dengan kelompok sebelum menulis. Peserta didik menyampaikan hasil diskusinya dengan kelompok dalam bentuk presentasi singkat. Pembelajaran akan efektif jika dilakukan dalam kelompok dengan tiga sampai 
lima orang peserta didik setiap kelompok. Dalam kelompok peserta didik diminta untuk membaca, membuat catatan kecil, menjelaskan, mendengarkan dan membagi ide bersama teman.

Kegiatan yang dilakukan setelah tahapan talk adalah peserta didik menuliskan (write) kembali pengetahuan atau informasi apa saja yang didapat dari tahapan sebelumnya. Pada tahapan write peserta didik mengkonstruksi sendiri hasil tahapan think dan talk dalam bentuk ringkasan materi yang dibuat secara individu.

Dalam Shoimin (2014: 214) langkahlangkah strategi Think Talk Write adalah:

1. Pendidik membagikan LKPD yang memuat soal yang harus dikerjakan oleh peserta didik serta petunjuk pelaksanaannya.

2. Peserta didik membaca masalah yang ada dalam LKPD dan membuat catatan kecil secara individu tentang apa yang ia ketahui dan tidak ketahui dalam masalah tersebut. Kemudian peserta didik membuat catatan kecil inilah akan terjadi proses berpikir (think) pada peserta didik. Setelah itu, peserta didik berusaha untuk menyelesaikan masalah tersebut secara individu. Kegiatan ini bertujuan agar peserta didik dapat membedakan atau menyatukan ide- ide yang terdapat pada bacaan untuk kemudian diterjemahkan ke dalam bahasa sendiri.
3. Pendidik membagi peserta didik dalam kelompok kecil (3- 5 peserta didik)

4. Peserta didik berinteraksi dan berkolaborasi dengan peserta didik satu grup untuk membahas isi catatan dari hasil (talk). Dalam kegiatan ini mereka menggunakan bahasa dan kata- kata mereka sendiri untuk menyampaikan ide- ide dalam diskusi

5. Peserta didik mengkonstruksi sendiri pengetahuan yang memuat kemampuan berpikir logis dalam bentuk tulisan (write).

6. Kegiatan akhir pembelajaran adalah membuat refleksi dan kesimpulan atas materi yang telah dipelajari. Sebelum itu dipilih beberapa orang peserta didik sebagai perwakilan kelompok untuk menyajikan jawabannya, sedangkan kelompok lain diminta memberikan tanggapan.

Kelebihan strategi Think Talk Write yaitu:

1. Dapat melatih peserta didik untuk berpikir secara logis dan sistematis.

2. Melatih peserta didik menuangkan ide dan gagasannya dari proses pembelajaran dalam sebuah tulisan yang ditulisnya sendiri.

3. Melatih peserta didik untuk mengemukakan ide secara lisan dan tulisan secara baik dan benar.

4. Dapat mendorong peserta didik untuk berpartisipasi dalam proses belajar mengajar. 
5. Melatih peserta didik untuk mengkonstruksikan sendiri pengetahuan sebagai hasil kolaborasi (write).

6. Melatih peserta didik untuk berpikir secara mandiri sehingga peserta didik mampu menemukan jawaban masalah yang dihadapinya dikemudian hari.

7. Memupuk keberanian peserta didik untuk mengemukakan pendapat, karena peserta didik harus mempersentasekan sendiri hasil belajarnya.

Kelemahan strategi Think Talk Write yaitu:

1. Bagi peserta didik yang lambat dalam berpikir akan mengalami kesulitan dalam mempelajari hal seperti ini.

2. Peserta didik kurang mampu menuangkan pikiran dalam tulisannya, akan mengalami hambatan tersendiri.

3. Adanya peserta didik yang malas berpikir untuk menemukan sesuatu. Oleh karena itu, pendidik harus senantiasa mendorong anak sehingga dapat berpikir secara cermat dan tepat.

Think Talk Write cocok digunakan karena melewati tahapan yang memang peserta didik berpikir terlebih dahulu (think, berbicara dengan teman kelompok (talk), dan menuliskan kembali (write). Ini akan meningkatkan aktivitas dalam pembelajaran matematika dan memberikan kesempatan kepada peserta didik untuk menyelesaikan masalah yang berkaitan dengan kemampuan berpikir logis secara individu maupun kerjasama dengan yang lainnya, sehingga partisipasi dalam belajar lebih banyak.

Penelitian yang dilakukan Wahyu dan Utari tahun 2013 yang berjudul "Kemampuan Komunikasi dan Berpikir Logis Matematik Serta Kemandirian Belajar Eksperimen Terhadap Siswa SMA Menggunakan Pembelajaran Berbasis Masalah dan Strategi Think Talk Write". Kesimpulan yang diperoleh adalah kemampuan komunikasi dan berpikir logis matematis peserta didik tergolong sedang. Sarannya agar dapat diajukan diantaranya adalah pengembangan kemampuan tingkat tinggi hendaknya lebih diutamakan untuk konten matematika yang esensial dan disertai dengan penyediaan bahan ajar dan bantuan pendidik yang sesuai dengan kebutuhan.

Berdasarkan penjelasan diatas, maka permasalahan yang dibahas apakah kemampuan apakah kemampuan berpikir logis peserta didik yang diajar dengan strategi Think Talk Write lebih tinggi dari pada kemampuan berpikir logis peserta didik menggunakan pembelajaran biasa di kelas VIII MTsN Kota Solok?. Sejalan dengan itu maka tujuan dari penelitian ini adalah untuk mengetahui kemampuan berpikir logis matematis peserta didik peserta didik dalam pembelajaran matematika dengan menerapkan strategi Think Talk Write lebih tinggi dari pada kemampuan peserta didik 
menggunakan pembelajaran biasa di kelas VIII MTsN Kota Solok.

\section{METODE PENELITIAN}

Sesuai dengan masalah yang diteliti, penelitian ini adalah eksperimen semu. Eksperimen semu adalah suatu kegiatan yang dilakukan terhadap manipulasi objek yang menggunakan kelas eksperimen dan kelas kontrol. Rancangan penelitian yang digunakan dalam penelitian ini adalah Randomized Control Grup Only Design. Penelitian ini di laksanakan kegiatan belajar mengajar di kelas eksperimen dan kelas kontrol. Kelas eksperimen adalah kelas yang sengaja diberi perlakuan yaitu penerapan srategi Think Talk Write sedangkan kelas kontrol tidak diberi perlakuan.

Tabel 1. Rancangan Penelitian.

\begin{tabular}{lcc}
\hline Kelas & Perlakuan & Tes \\
\hline Eksperimen & $\mathrm{X}$ & $\mathrm{T}$ \\
Kontrol & - & $\mathrm{T}$ \\
\hline
\end{tabular}

Sumber: Sumadi (2004: 118)

Dengan:
$X$ : Strategi Think Talk Write.
$\mathrm{T}$ : Tes kemampuan berpikir logis

Variabel dalam penelitian ini adalah: (1).Variabel bebas yaitu strategi Think Talk Write, dan (2). Variabel terikat yaitu kemampuan berpikit logis matematis peserta didik kelas VIII MTsN Kota Solok

Penelitian ini dilaksanakan pada kelas VIII MTsN Kota Solok Tahun ajaran 2018/2019 semester ganjil. Populasi dalam penelitian ini adalah peserta didik kelas VIII MTsN Kota Solok Tahun ajaran 2018/2019. Data nilai tes awal kemampuan berpikir logis matematis peserta didik dijadikan sebagai data populasi. Pada penelitian ini ada dua kelas yang digunakan sebagai sampel. Sampel merupakan bagian dari populasi yang mempunyai ciri-ciri atau keadaan tertentu yang akan diteliti. Untuk mendapatkan sampel yang representatif peneliti, berpatokan pada pendapat Suharsimi (2002:176) yaitu: “Pengambilan sampel haruslah dilakukan sedemikian rupa sehingga diperoleh sampel yang benar-benar dapat berfungsi sebagai contoh atau dapat menggambarkan keadaan populasi yang sebenarnya dengan istilah sampel harus representatif."

Data populasi yang telah diambil berdistribusi normal, memiliki variansi yang homogen, dan rata-rata yang sama dan selanjutnya sampel diambil secara Random Sampling. Dengan demikian, terpilihlah kelas $\mathrm{VIII}_{\mathrm{G}}$ sebagai kelas eksperimen dan kelas $\mathrm{VIII}$ sebagai kelas kontrol. Data yang digunakan dalam penelitian ini adalah data primer dan data sekunder. 
Data primer diperoleh dari kemampuan berpikir logis selama proses pembelajaran berlangsung dan tes berpikir logis peserta didik kelas sampel, sedangkan data sekunder adalah adalah populasi peserta didik dan nilai murni hasil ulangan harian 1 semester 1 kelas VIII MTsN Kota Solok tahun pelajaran 2018/ 2019.

Instrumen yang digunakan dalam penelitian ini adalah tes kemampuan berpikir logis matematis peserta didik yang dilaksanakan setelah kelas eksperimen dan kelas kontrol selesai. Soal tes kemampuan berpikir logis matematis pesera didik terdiri dari 6 (enam) butir soal tes bentuk essay. Hasil uji coba menunjukkan bahwa kemampuan berpikir logis matematis lebih tinggi. Pengumpulan data dilkukan dengan menggunakan tes essay yang diberikan pada pertemuan terakhir. Setelah tes dilaksanakan, lembar jawaban peserta didik dikumpulkan dan diperiksa.

Prosedur penelitian ini adalah (1) Tahap persiapan. Tahap ini terdiri dari: menetapkan tempat penelitian, melakukan observasi ke tempat penelitian, menetapkan jadwal penelitian, menentukan populasi dan sampel, menyusun dan mempelajari materi penelitian, mempersiapkan instrumen penelitian atau segala sesuatu yang berhubungan dengan pelaksanaan penelitian, melakukan vailidasi instrumen oleh validator, dan mempersiapkan surat izin penelitian (2) Tahap pelaksanaan.
Dalam tahap ini, pelaksanaan penelitian di kelas eksperimen dan pelaksanaan penelitian di kelas kontrol. Penelitian pada kelas eksperimen dilakukan dengan menggunakan strategi Think Talk Write, sedangkan kelas kontrol dilakukan dengan menggunakan model pembelajaran biasa (K13) dan (3) Tahap akhir yaitu pendidik memberikan tes pada kedua kelas sampel setelah pokok materi selesai diberikan, mengolah data dari kedua kelas sampel, menarik kesimpulan dari hasil yang diperoleh sesuai teknik analisis data yang digunakan dan membuat laporan penelitian.

Analisis data yang digunakan satu arah dengan uji t. Uji ini digunakan untuk mengetahui apakah kemampuan berpikir logis matematis peserta didik pada kelas eksperimen lebih tinggi daripada kemampuan berpikir logis matematis peserta didik pada kelas kontrol. Rumus uji $t$ adalah sebagai berikut:

$$
t=\frac{\overline{X_{1}}-\overline{X_{2}}}{S \sqrt{\frac{1}{n_{1}}+\frac{1}{n_{2}}}}
$$

Dengan:

$$
S=\sqrt{\frac{\left(n_{1}-1\right) S_{1}{ }^{2}+\left(n_{2}-1\right) S_{2}{ }^{2}}{n_{1}+n_{2}-2}}
$$

\section{Dimana:}

$\overline{X_{1}}=$ nilai rata-rata kelas eksperimen

$\overline{X_{2}}=$ nilai rata-rata kelas kontrol

$n_{1}=$ jumlah peserta didik kelas eksperimen

$n_{2}=$ jumlah peserta didik kelas kontrol

$S_{1}{ }^{2}=$ simpangan baku kelas eksperimen 
$S_{1}{ }^{2}=$ simpangan baku kelas kontrol

Uji $t$ yang dilakukan harus terpenuhi dua syarat, yaitu sampel berasal dari populasi yang terdistribusi normal dan kedua kelas memiliki variansi yang homogen. Pada penelitian ini, pengujian dilakukan untuk mengetahui kemampuan berpikir logis matematis peserta didik melalui strategi Think Talk Write lebih tinggi dari pada kemampuan berpikir logis matematis peserta didik yang diajar dengan pembelajaran biasa (K13).

\section{HASIL DAN PEMBAHASAN}

Data yang dideskripsikan adalah kemampuan berpikir logis matematis peserta didik dalam belajar matematika. Kemampuan berpikir logis peserta didik dalam belajar matematika diperoleh dari hasil tes akhir.

Jumlah peserta didik pada kelas eksperimen yang menerapkan strategi Think Talk Write (kelas VIII G ) 41 orang, dan ada 4 orang yang tidak mengikuti tes sehingga yang mengikuit tes hanya 37 orang, begitu juga halnya dengan kelas kontrol, yaitu (kelas VIII $\mathrm{E}_{\mathrm{E}}$ ) berjumlah 40 orang, dan ada 2 orang yang tidak mengikuti tes sehingga yang mengikuti tes hanya 38 orang. Hasil deskripsi data yang diperoleh berdasarkan tes yang telah dilakukan dapat dilihat pada Tabel 2.
Tabel 2. Deskripsi Data Kemampuan Berpikir Logis

Kelas Sampel

\begin{tabular}{ccc}
\cline { 2 - 3 } & Eksperimen & Kontrol \\
\hline Nilai Max & 95,83 & 90,28 \\
Nilai Min & 66,67 & 58,33 \\
$\bar{x}$ & 80,81 & 75,03 \\
S & 7,40 & 8,37 \\
\hline
\end{tabular}

Berdasarkan tabel, dapat dilihat bahwa rata-rata kemampuan berpikir logis matematis peserta didik kelas eksperimen dengan menerapkan strategi Think Talk Write memiliki rata-rata lebih tinggi dari pada kemampuan berpikir logis matematis peserta didik kelas kontrol dengan menggunakan model pembelajaran biasa (K13). Berikut hasil nilai tes akhir kemampuan berpikir logis matematis peserta didik pada masing-masing indikator:

Tabel 3. Pengelompokan Nilai Tes Akhir Kemampuan Berpikir Logis Matematis Kelas Eksperimen dan Kelas Kontrol

\begin{tabular}{llcc}
\hline No & \multicolumn{1}{c}{$\begin{array}{c}\text { Indikator Berpikir } \\
\text { Logis }\end{array}$} & Eksperimen & Kontrol \\
\hline 1 & $\begin{array}{l}\text { Mengidentifikasi } \\
\text { hubungan antar fakta } \\
\text { dalam menyelesaikan } \\
\text { masalah } \\
\text { Menyelesaikan }\end{array}$ & 81,64 & 77,63 \\
$2 \quad \begin{array}{l}\text { permasalahan dengan } \\
\text { memberikan alasan }\end{array}$ & 81,41 & 75,10 \\
& $\begin{array}{l}\text { Membuat kesimpulan } \\
\text { berdasarkan } \\
\text { keserupaan dua } \\
\text { proses }\end{array}$ & 79,36 \\
\hline \multicolumn{2}{c}{ Rata-rata } & 80,81 & 75,03 \\
\hline
\end{tabular}


Analisis data kemampuan berpikir logis matematis peserta didik kelas eksperimen dan kelas kontrol dilakukan untuk menguji hipotesis yang telah dirumuskan, diterima atau ditolak. Untuk mengetahui hal tersebut, terlebih dahulu dilakukan uji normalitas dan uji homogenitas variansi terhadap kemampuan berpikir logis matematis peserta didik pada kedua sampel. Hasil perhitungan uji normalitas kedua kelas sampel berdistribusi normal dan hasil uji homogenitas kedua sampel mempunyai variansi yang homogen. Hasil uji normalitas kedua sampel disajikan dalam

Tabel 4. Uji Normalitas

\begin{tabular}{lcc}
\hline \multicolumn{1}{c}{ Kelas } & $\mathrm{L}_{0}$ & $\mathrm{~L}_{\text {tabel }}$ \\
\hline Eksperimen & 0.14 & 0.14 \\
Kontrol & 0.13 & 0.14 \\
\hline
\end{tabular}

Berdasarkan hasil uji normalitas yang diperoleh dari masing-masing kelas sampel, maka dapat disimpulkan bahwa kedua kelas sampel berdistribusi normal. Hal ini dikarenakan $L_{\text {tabel }}$ masing-masing kelas sampel lebih besar dari $L_{0}$ yaitu untuk kemampuan berpikir logis matematis pada kelas eksperimen dan kelas kontrol berturutturut diperoleh $L_{0}=0,14$ dan $L_{0}=0,13$; sedangkan $L_{\text {tabel }}=0,14$ dan $L_{\text {tabel }}=0,14$.

Uji homogenitas dilakukan dengan tujuan melihat kedua kelas sampel mempunyai variansi yang homogen atau tidak. Adapun kriteria pengujian yang digunakan adalah: $X_{\text {hitung }}^{2}=0.52$ dan sedangkan $\quad X_{\text {tabel }}^{2}=3,8$
Dengan $\alpha=0,05$ dan $d f=1$. Berdasarkan hasil yang diperoleh, terlihat bahwa $X_{\text {hitung }}^{2}<$ $X_{\text {tabel }}^{2}$. Hal ini menunjukkan bahwa kedua sampel memiliki variansi yang homogen.

Berdasarkan uji normalitas dan uji homogenitas variansi yang telah dilakukan ternyata kedua sampel mempunyai variansi yang homogen, dengan demikian untuk mengetahui hipotesis diterima atau ditolak digunakan uji-t. Adapun kriteria pengujian yang digunakan adalah: $t_{\text {hitung }}>t_{\text {tabel }}$, maka kemampuan berpikir logis matematis peserta didik melalui model strategi Think Talk Write lebih tinggi daripada kemampuan berpikir logis matematis peserta didik yang diajar dengan pembelajaran biasa (K13).

Berdasarkan hasil perolehan data kemampuan berpikir logis matematis, diperoleh berturut-turut $t_{\text {hitung }}=3,19$ dan $t_{\text {tabel }}=1,64$; dengan $\alpha=0.05$ dan $d f=73$. Beradasarkan hasil yang diperoleh, terlihat bahwa $t_{\text {hitung }}>t_{\text {tabel }}$. Hal ini menunjukkan bahwa kemampuan berpikir logis matematis matematis peserta didik yang diajar melalui strategi Think Talk Write lebih tinggi dari pada kemampuan berpikir logis matematis peserta didik yang diajar dengan pembelajaran biasa di kelas VIII MTsN Kota Solok Tahun Ajaran 2018/2019.

Hal ini berhubungan dengan penelitian yang telah dilakukan Wahyu dan Sumarmo, yang hanya di disain kelompok kontrol dan postes saja, dan bertujuan menelaah peranan 
pembelajaran berbasis masalah disertai strategi Think, Talk, and Write (PBM-TTW) terhadap kemampuan berpikir logis, kritis, dan kreatif matematik peserta didik. Penelitian Wahyu dan Sumarmo ini menunjukkan bahwa kemampuan komunikasi matematis dan berpikir logis peserta didik tergolong sedang, yakni 61,21. Penelitian ini lebih baik dan mendukung penelitian sebelumnya, karena penelitian sebelumnya tidak menggunakan media LKPD, sementara pada penelitian ini menggunakan media Lembar Kerja Peserta Didik (LKPD) yang mendukung proses pembelajaran peserta didik, serta menggunakan dua kelas yakni kelas eksperimen dan kelas kontrol, jadi ada pembanding antara kemampuan berpikir logis matematis peserta didik yang menggunakan strategi Think Talk Write dengan yang tidak menggunakan strategi Think Talk Write.

\section{SIMPULAN DAN SARAN}

\section{Simpulan}

Berdasarkan hasil analisis data dan pembahasan maka dapat disimpulkan bahwa kemampuan berpikir logis matematika peserta didik yang menggunakan strategi Think Talk Write lebih tinggi dibandingkan dengan kemampuan berpikir logis matematis peserta didik yang diajar secara biasa. Hal ini dapat dilihat dari rata-rata kemampuan berpikir logis matematis pada saat tes akhir. Nilai rata-rata kelas eksperimen yang terdiri dari 37 orang yaitu 80,81 lebih tinggi dibanding nilai rata-rata kelas kontrol yang juga terdiri dari 38 orang yaitu 75,03.

\section{Saran}

1. Agar pendidik matematika SMP/ MTsN, khususnya MTsN Kota Solok agar menggunakan strategi Think-Talk-Write sebagai salah satu alternatif terhadap kemampuan berpikir logis matematika peserta didik

2. Melihat kemampuan berpikir logis matematis yang diperoleh peserta didik lebih tinggi dalam mempelajari pokok bahasan Pola Bilangan dan Barisan Bilangan dengan menggunakan strategi Think-Talk-Write, disarankan supaya dilakukan penelitian lebih lanjut pada pokok bahasan lain.

3. Agar seluruh peserta didik di MTsN Kota Solok lebih menyukai cara belajar student centered.

4. Agar pada penelitian berikutnya peneliti mempertimbangkan waktu, supaya tidak terpakai jam pelajaran pendidik lainnya.

\section{REFERENSI}

Arikunto, Suharsimi. 2002. Prosedur Penelitian (Suatu Pendekatan Praktek). Jakarta: Rineka Cipta.

Andriawan, Budi. 2014. "MATHEdunesa Jurnal Ilmiah Pendidikan Matematika: Identifikasi Kemampuan Berpikir Logis Dalam Pemecahan Masalah Matematika Pada Siswa Kelas VIII-1 SMP Negeri Sidoarjo 3:Hal. 43- 44 . 
Asril Rais. 2017. "Semnastika UNIMED: Perbedaan Kemampuan Berpikir Logis Siswa Dengan Pendekatan Konstruktivisme dan Pendekatan Klasikal Pada Siswa SMP Terpadu AlBukhari Muslim Medan: ISBN 978-60217980.

Dwi Novita Sari. 2018. Penerapan Strategi Think Talk Write Untuk Meningkatkan Kemampuan Pemahaman Matematis Pada Pokok Bahasan Bilangan Berpangkat: 1. Hal 97-103.

Edy Suyatno. 2016. Pembelajaran Matematika dengan Strategi Think Talk Write Berbasis Learning Journal untuk Meningkatkan Kemampuan Menulis Matematis: 7. Hal 58-65.

Huda, Miftahul. 2013. Model- Model Pengajaran dan Pembelajaran (Isu - Isu Metodis dan Pragmatis). Yogyakarta: Pustaka Pelajar.

Nunun Elida. 2012. Meningkatkan Kemampuan Komunikasi Matematik Peserta Didik Sekolah Menengah Pertama Melalui Pembelajaran Think Talk Write (TTW): 2. Hal 178- 185 .
Suherman, Erman. 2003. Strategi Pembelajaran Matematika Kontemporer. Bandung: Universitas Pendidikan Indonesia.

Suryabrata, Sumadi. 2004. Metode Penelitian. Jakarta: Raja Grafindo.

Tantan, Ali. 2015. "Jurnal Riset Pendidikan Matematika: Keefektifan

Permasalahan Berbasis Masalah dan Problem Posing Ditinjau dari Kemampuan Berfikir Logis dan Kritis 2:Hal. 107- 120.

Utari, Sumarmo, Rafiq, Hamidah dan Ratna Sariningsih. 2012. "Kemampuan dan Disposisi Berpikir Logis, Kritis, dan Kreatif Matematis Eksperimen Terhadap Siswa SMA Menggunakan Pembelajaran Berbasis Masalah dan Strategi Think Talk Write": 17. Hal 1733.

Wahyu, Utari. 2013."Kemampuan Komunikasi dan Berpikir Logis Matematik Serta Kemandirian Belajar Eksperimen Terhadap Siswa SMA Menggunakan Pembelajaran Berbasis Masalah dan Strategi Think Talk Write": 2. Hal 1- 14. 